\title{
COMPARATIVE ANALYSIS OF EMPLOYMENT BY ECONOMIC ACTIVITIES IN BULGARIA AND EU-28
}

\author{
Konstantin Kolev ${ }^{1}$
}

DOI: https://doi.org/10.31410/ERAZ.S.P.2019.109

\begin{abstract}
The paper's goal is to analyze the employment in Bulgaria and EU-28 by economic activities of NACE Rev. 2 Statistical Classification of Economic Activities in the European Community, and on this basis to reveal opportunities for increasing the employment in Bulgaria. The analysis of employment by economic activities is based on shift-share analysis and the concept of the economic base. The first one decomposes the changes in the number of employees on three parts: national, industrial and regional. From the three components of the change the 'regional share' is the most important. It reveals the economic activities, which have opportunities for growth in the respective region (in current study in Bulgaria) due to its favourable conditions. According to the concept of the economic basis the local economy (in current study the economy of Bulgaria) is divided on two sectors - basic and non-basic. The economic sectors defined as basic form the economic base of the region and all other economic sectors thrive by serving the basic ones. To determine the basic economic sectors of the respective regional economy (in current study the economy of Bulgaria) location quotients are calculated. The results of the two methods are summarized on the four-quadrant table, which allows the economic sectors to be systematized into four groups - growing, transforming, declining and emerging. The most significant sectors, which contribute to high extent for increasing of employment in the region (Bulgaria) are those ones classified as growing.
\end{abstract}

Keywords: employment, shift-share analysis, conception of economic base, location quotients, economic sectors.

\section{INTRODUCTION}

$\mathrm{T}$ he average annual employment rate in Bulgaria in 2017 for the age group 20 to 64 years is $71 \%$ and is below the target level of $75 \%$, that is pointed out in Europe 2020 strategy. The last one is difficult for achievement due to the fact that in 2017 the number of employed aged 15-64 is with 419.46 thousand persons smaller than their number in pre-crisis 2007 year [1]. In order to overcome these negative findings, the purpose of the present study is to analyze the employment in Bulgaria and EU-28 by economic activities of NACE Rev. 2 Statistical Classification of Economic Activities in the European Community, and on this basis to reveal opportunities for increasing the employment in Bulgaria.

\section{SHIFT-SHARE ANALYSIS AND THE CONCEPT OF THE ECONOMIC BASIS}

Different methods of quantitative analysis of regional employment are known. Among them, according to some authors, the most popular methods are shift-share analysis and the concept of the economic basis, which uses location quotients. They are reliable tools for making adequate decisions by national and regional development planning agencies and departments because of the following reasons: firstly, their implementation is provided with quantitative data unlike the subjective approaches that rely mainly on expert opinions; secondly, the obtained results are

University of Forestry, 10 Kliment Ohridsky Blvd., Sofia 1797, Bulgaria 
logical and clear to understand; thirdly, they permit comparison in time between region located in different parts of the world $[2,3]$. Because of these reasons the methods mentioned above are perceived as leading for the research. Their essence is presented in the lines below.

\subsection{Shift-share analysis}

Shift-share analysis is a popular method used to analyze the changes in the number of employees in some region for a definite period of time. Usually the changes in the number of employees in the region are compared with the changes in the number of employees at national level. ${ }^{2}$ Shiftshare analysis decomposes the changes in the number of employees on three parts: national share, industrial share and regional share $[4,5,6,7,8,9]$.

The component national share ( $\mathrm{NS}_{\mathrm{r}}$ ) measures the change in the number of employed persons on regional level if employment in the region alters with the same rate of growth $\left(\mathrm{g}_{\mathrm{n}}\right)$ as the national economy [2].

$$
N S_{r}=\sum_{i=1}^{N} E_{i r}^{t} g_{n}
$$

- $\mathrm{NS}_{\mathrm{r}}$ - the national share for the region $\mathrm{r}$, number of employed;

- $\mathrm{E}_{\mathrm{ir}}^{\mathrm{t}}$ - the employed persons in economic activity $\mathrm{i}$ of region $\mathrm{r}$ at the begging of the analyzed period;

- $\mathrm{N}$ - the number of economic activities;

- $g_{n}$ - the growth rate of employed persons on national level for the analyzed period (index of national share.

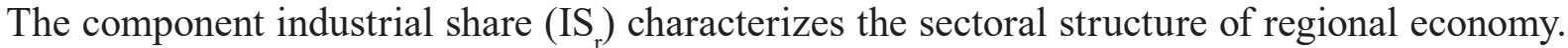
It reflects the change in the number of employed on regional level if each sector of regional economy grows with the difference between the national growth rate for this sector $\left(\mathrm{g}_{\text {in }}\right)$ and the growth rate of national economy $\left(\mathrm{g}_{\mathrm{n}}\right)$ for the studied period.

$$
I S_{r}=\sum_{i=1}^{N} E_{i r}^{t}\left(g_{\text {in }}-g_{n}\right)
$$

- IS ${ }_{r}$ - the industrial share for region $r$, number of employed;

- $g_{\text {in }}$ - the growth rate in employment for economic activities $i$ at national level.

The component regional share $\left(\mathrm{RS}_{\mathrm{r}}\right)$ is also known as the differential share, the competitive effect and the local factor effect. It measures the change in the number of employed persons in a given economic activity at regional level, which is caused by the differences in the growth rates of the employed in the respective sector at regional level $\left(\mathrm{g}_{\mathrm{ir}}\right)$ and national level $\left(\mathrm{g}_{\mathrm{in}}\right)$. The regional share index $\left(\mathrm{g}_{\mathrm{ir}}-\mathrm{g}_{\text {in }}\right)$ makes it possible to reveal the economic activities that have potential for development and growth in the respective region $[2,7,10]$. When the value of regional share $\left(\mathrm{RS}_{\mathrm{r}}\right)$ is positive the conclusion which is drawn up is that due to better opportunities in the region some of its economic activities have a higher rate of growth in the number of employed $\left(\mathrm{g}_{\mathrm{ir}}\right)$ than the rate of growth in employment of the same economic activities at national level $\left(\mathrm{g}_{\mathrm{in}}\right)$. In current study under region/regional level or local level is understood the territory of Bulgaria, and under national level is understood the territory of EU-28. 
The last one means tnat the regional share index $\left(\mathrm{g}_{\mathrm{ir}}-\mathrm{g}_{\text {in }}\right)$ is positive. At the same if $\mathrm{RS}_{\mathrm{r}}$ is negative, the conclusion which is drawn up is that due to worse conditions in the region some of its economic activities have a lower rate of growth in the number of employed $\left(g_{\text {ir }}\right)$ than the rate of growth in employment of the same economic activities at national level $\left(\mathrm{g}_{\mathrm{in}}\right)$. The regional share is considered as the most important component of the three presented above. It draws attention to the economic activities that are able to take advantages of the appropriate opportunities, which the region offers, and develop successfully in it by helping to increase employment [2, 4, $7,8,11,12]$. The regional share is calculated by means of formula $(3)[2,4]$ :

$$
R S_{r}=\sum_{i=1}^{N} E_{i r}^{t}\left(g_{i r}-g_{i n}\right)
$$

- $\mathrm{RS}_{\mathrm{r}}$ - the regional share for region $\mathrm{r}$, number of employed;

- $\left(\mathrm{g}_{\mathrm{ir}}-\mathrm{g}_{\text {in }}\right)$ - the index of regional share;

$-g_{i r}$ - the growth rate of employment in economic activity $i$ on regional level for the analysed period.

The sum of the three shares examined above represents the growth in the number of employed persons $\left(\mathrm{TS}_{\mathrm{r}}\right)$ for the analyzed period in the respective district. It is calculated through formula (4) $[2,4]$ :

$$
T S_{r}=\sum_{i=1}^{N} E_{i r}^{t} g_{n}+\sum_{i=1}^{N} E_{i r}^{t}\left(g_{i n}-g_{n}\right)+\sum_{i=1}^{N} E_{i r}^{t}\left(g_{i r}-g_{i n}\right)
$$

The period of the research should be carefully defined. The first year may be two, five or ten years back in time in comparison with the last one, and they have to be in the same phase of the business cycle. In this way the changes will be reflected more precisely [2]. In relation with the mentioned above and taking into account the available data provided by the EUROSTAT, the shift-share analysis is realized for the period 2007-2017.

\subsection{The concept of the economic basis}

According to the concept of the economic basis, the local economy is divided on two main sectors - basic and not basic. The first one includes companies that realize their production outside the borders of the region, while the second is compounded by companies that sell their production on the local/regional market. The concept of the economic basis is grounded on the assumption that the basic industries form the economic base of the region, and all other economic activities thrive by serving the basic ones. The local economy is stable when it stimulates the development of those economic activities that are export-oriented and provide financial revenues from outside the territory in which they operate. To determine the basic economic activities for the respective regional economy, a specialization (localization) coefficient $\left(\mathrm{CS}_{\mathrm{ir}}\right)$ is used. It presents a ratio between the relative share of employed person in a particular economic activity at the local level and the relative share of employed person in the same economic activity at national level. The specialization index is a reliable tool for identifying correctly the basic economic activities $[2,3,9,13,14,15,16]$ : 


$$
C S_{i r}=\left(\frac{E_{i r}}{E_{r}}\right):\left(\frac{E_{n i}}{E_{n}}\right)
$$

- $\mathrm{CS}_{\mathrm{ir}}$ is the index of specialization for economic activity $\mathrm{i}$ in district $\mathrm{r}$;

$-\mathrm{E}_{\mathrm{ir}}$ - the number of employed persons in economic activity $\mathrm{i}$ in district $\mathrm{r}$;

$-\mathrm{E}_{\mathrm{r}}-$ the number of employed persons in district $\mathrm{r}$;

$-\mathrm{E}_{\mathrm{n}}$ - the number of employed persons in economic activity $\mathrm{i}$ on national level;

- $\mathrm{E}_{\mathrm{n}}$ - the number of employed persons on national level.

It should be mentioned that the obtained results are reliable under the assumption that the technological level of the enterprises in the respective industry is approximately equal [15]. The minimum value of the coefficient of specialization is zero and the maximum one is not limited [14]. If the value of the coefficient is bigger than 1, it can be assumed that the respective economic activity is basic for the local economy. Basic economic activities are defined as specialized. Due to the specialization it is considered that in them the local economy has competitive advantages over the same in other administrative-territorial units.

The results from shift-share analysis and economic basis analysis can be summarized on a two-dimensional cartesian coordinate system. In this respect on the abscissa are set up the regional share indexes $\left(\mathrm{g}_{\mathrm{ir}}-\mathrm{g}_{\mathrm{in}}\right)$, and on the ordinate are set up the values of the coefficients of specialization $\left(\mathrm{CS}_{\mathrm{ir}}\right)$. Since the specialization index is normalized from zero to infinity from its value is subtracted 1. In this way the economic activities that are basic for the local economy will be located in the first and second quadrants of the coordinate system and those with coefficient of specialization less than one will accept negative values and will be placed in the third and fourth quadrants (see Table 1) [4, 12, 17, 18, 19].

Table 1: Visualization of the indexes of regional share and specialization $[4,12]$

\begin{tabular}{|c|l|l|}
\hline Indexes & \multicolumn{1}{|c|}{$\mathrm{g}_{\mathrm{ir}}-\mathrm{g}_{\text {in }}<0$} & \multicolumn{1}{c|}{$\mathrm{g}_{\mathrm{ir}}-\mathrm{g}_{\text {in }}>0$} \\
\hline $\mathbf{C S}_{\text {ir }}>\mathbf{1}$ & $\begin{array}{l}\text { II quadrant }- \text { basic economic } \\
\text { activities with deteriorated } \\
\text { conditions for development } \\
\text { on the respected territory } \\
\text { (Transforming Industries). }\end{array}$ & $\begin{array}{l}\text { I quadrant }- \text { basic economic } \\
\text { activities with opportunities for } \\
\text { development on the respected } \\
\text { territory (Growing Base } \\
\text { Industries). }\end{array}$ \\
\hline $\mathbf{C S}_{\text {ir }}<\mathbf{1}$ & $\begin{array}{l}\text { III quadrant }- \text { not specialized } \\
\text { economic activities without } \\
\text { opportunities for development } \\
\text { on the respected territories } \\
\text { (Declining Industries). }\end{array}$ & $\begin{array}{l}\text { IV quadrant }- \text { not specialized } \\
\text { economic activities with } \\
\text { opportunities for development } \\
\text { on the respected territory } \\
\text { (Emerging Industries). }\end{array}$ \\
\hline
\end{tabular}

\section{COMPARATIVE ANALYSIS OF EMPLOYMENT BY ECONOMIC ACTIVITIES IN BULGARIA AND EU-28}

The analysis of regional employment by economic activities is based on the methodology presented in paragraph (2) and information from EUROSTAT about the number of employed persons in Bulgaria and EU-28 in 2007 and 2017, grouped by sectors of ISIC Rev.4/NACE Rev.2. (see table 2) 
Table 2: Systematization of ISIC Rev.4/NACE Rev.2. Sectors

\begin{tabular}{|l|l|}
\hline $\begin{array}{l}\text { ISIC Rev.4/NACE } \\
\text { Rev.2 sections }\end{array}$ & Descriptions \\
\hline A & Agriculture, forestry and fishing \\
\hline B, D and E & Industry (except construction) \\
\hline C & Manufacturing \\
\hline F & Construction \\
\hline G, H and I & $\begin{array}{l}\text { Wholesale and retail trade, transport, accommodation and food service ac- } \\
\text { tivities }\end{array}$ \\
\hline J & Information and communication \\
\hline K & Financial and insurance activities \\
\hline L & Real estate activities \\
\hline M and N & $\begin{array}{l}\text { Professional, scientific and technical activities; administrative and support } \\
\text { service activities }\end{array}$ \\
\hline O, P and Q & $\begin{array}{l}\text { Public administration, defense, education, human health and social work } \\
\text { activities }\end{array}$ \\
\hline R, S, T and U & $\begin{array}{l}\text { Arts, entertainment and recreation; other service activities; activities of } \\
\text { household and extra-territorial organizations and bodies }\end{array}$ \\
\hline
\end{tabular}

Table 3: Index of National, Industrial and Regional Share and Specialization Index of Bulgaria

\begin{tabular}{|c|c|c|c|c|c|c|c|c|c|c|c|c|}
\hline \multirow{2}{*}{$\begin{array}{c}\text { ISIC } \\
\text { Rev.4/ } \\
\text { NACE } \\
\text { Rev.2 } \\
\text { sections }\end{array}$} & \multicolumn{2}{|c|}{$\begin{array}{l}\text { Employed persons } \\
\text { in } 2007 \text {, thousands }\end{array}$} & \multicolumn{2}{|c|}{$\begin{array}{l}\text { Employed persons } \\
\text { in } 2017 \text {, thousands }\end{array}$} & \multirow{2}{*}{$\mathrm{g}_{\mathrm{n}}$} & \multirow{2}{*}{$\left(g_{\text {in }}-g_{n}\right)$} & \multirow{2}{*}{$\left(g_{i r}-g_{\text {in }}\right)$} & \multirow{2}{*}{$\mathrm{CS}_{\mathrm{ir}}$} & \multirow{2}{*}{$\begin{array}{c}\text { NSr, } \\
\text { thousands } \\
\text { employed }\end{array}$} & \multirow{2}{*}{$\begin{array}{l}\text { ISr, thou- } \\
\text { sands } \\
\text { employed }\end{array}$} & \multirow{2}{*}{$\begin{array}{c}\text { RSr, } \\
\text { thousands } \\
\text { employed }\end{array}$} & \multirow{2}{*}{ Quadrant } \\
\hline & $\begin{array}{l}\text { Bul- } \\
\text { garia }\end{array}$ & EU-28 & $\begin{array}{l}\text { Bul- } \\
\text { garia }\end{array}$ & EU-28 & & & & & & & & \\
\hline $\mathrm{A}$ & 723.86 & 12676.75 & 664.91 & 10433.83 & 0.017 & -0.194 & 0.095 & 3.762 & 12.06 & -140.13 & 69.12 & I \\
\hline $\begin{array}{l}\mathrm{B}, \mathrm{D} \\
\text { and E }\end{array}$ & 835.58 & 38903.02 & 708.13 & 36183.45 & 0.017 & -0.087 & -0.083 & 1.272 & 13.92 & -72.33 & -69.04 & II \\
\hline $\mathrm{C}$ & 723.20 & $35,322.7$ & 615.19 & 32629.68 & 0.017 & -0.093 & -0.073 & 1.219 & 12.05 & -67.19 & -52.87 & II \\
\hline $\mathrm{F}$ & 251.10 & 17583.71 & 175.44 & 14997.16 & 0.017 & -0.164 & -0.154 & 0.803 & 4.18 & -41.12 & -38.72 & III \\
\hline $\mathrm{G}, \mathrm{H}$ and $\mathrm{I}$ & 866.07 & 55739.49 & 889.38 & 58436.37 & 0.017 & 0.032 & -0.021 & 0.955 & 14.43 & 27.48 & -18.59 & III \\
\hline $\mathrm{J}$ & 68.37 & 6082.68 & 94.24 & 7086.03 & 0.017 & 0.148 & 0.213 & 0.765 & 1.14 & 10.14 & 14.59 & IV \\
\hline K & 51.56 & 6204.34 & 64.91 & 5917.34 & 0.017 & -0.063 & 0.305 & 0.602 & 0.86 & -3.24 & 15.74 & IV \\
\hline $\mathrm{L}$ & 20.81 & 2445.69 & 27.02 & 2585.01 & 0.017 & 0.040 & 0.241 & 0.592 & 0.35 & 0.84 & 5.02 & IV \\
\hline $\mathrm{M}$ and $\mathrm{N}$ & 200.07 & 24982.50 & 245.56 & 30329.07 & 0.017 & 0.197 & 0.013 & 0.500 & 3.33 & 39.48 & 2.67 & IV \\
\hline $\mathrm{O}, \mathrm{P}$ and $\mathrm{Q}$ & 612.47 & 50964.14 & 544.13 & 55588.63 & 0.017 & 0.074 & -0.202 & 0.674 & 10.20 & 45.37 & -123.92 & III \\
\hline $\begin{array}{l}\mathrm{R}, \mathrm{S}, \mathrm{T} \\
\text { and } \mathrm{U}\end{array}$ & 96.86 & 13260.95 & 111.65 & 14379.90 & 0.017 & 0.068 & 0.068 & 0.469 & 1.61 & 6.56 & 6.62 & IV \\
\hline Total & 4449.9 & 264166.0 & 4140.5 & 268566.4 & - & - & - & - & 74.13 & -194.14 & -189.38 & - \\
\hline
\end{tabular}

Sector A is the only basic sector for which there are suitable development conditions on the territory of Bulgaria (see table 3). Due to this it is positioned in first quadrant of the coordinate system. The number of persons employed in sector A in 2017 is 664910 . Under the influence of the regional share, the number of employed in the sector for the surveyed period increased with 69120 persons (see table 3).

Sectors (B, D and E) and C are distributed in quadrant II, which means that they are basic for the economy of Bulgaria. By the way during the investigated period on the territory of Bulgaria the conditions for development of these economic activities are not suitable. The effect of re- 
gional share on employment is negative and under its influence in sectors $(\mathrm{B}, \mathrm{D}$ and $\mathrm{E})$ and $\mathrm{C}$ are lost respectively 69040 and 52870 working places (see table 3).

Poorly developed on the territory of Bulgaria are the economic activities F, $(\mathrm{G}, \mathrm{H}$ and $\mathrm{I}),(\mathrm{O}, \mathrm{P}$ and Q) which are distributed in the third quadrant of the coordinate system (see table 3). All of them have negative regional shares respectively 38 720, 18 590, 123920 working places. The latter reflects the unfavourable conditions for these sectors development on the territory of Bulgaria. Regarding sector $(\mathrm{G}+\mathrm{H}+\mathrm{I})$, it should be noted that there is a potential for its development on the territory of Bulgaria and its transformation into a basic one. The prerequisites for this are the favorable location of the state and its strategic place in the regional transport system as well as the rich cultural and historical heritage.

During the period 2007-2017 in Bulgaria there are good opportunities for development of sectors $\mathrm{J}, \mathrm{K}, \mathrm{L},(\mathrm{R}, \mathrm{S}, \mathrm{T}$ and $\mathrm{U})$ which are set up in fourth quadrant of the coordinate system. Their regional share is positive and amount respectively to 14 590, 15740,5020 and 6620 new working places (see table 3).

\section{CONCLUSION}

On the grounds of the employment's analysis in Bulgaria the following conclusions can be done: Firstly, through the existing regulatory framework and strategic documents should be encouraged the development of these economic activities of NACE Rev. 2, which are basic for the economy and on the territory of Bulgaria there are suitable conditions for their development. These are the economic activities distributed in the first quadrant of the coordinate system (the so called 'Growing Base Industries'). For Bulgaria in first quadrant is positioned only economic activity 'Agriculture, Forestry and Fishery' (A). Secondly, through existing regulatory framework and strategic documents should be encouraged the development of these economic activities of NACE Rev. 2, which are not basic for the economy, but on the territory of Bulgaria there are suitable conditions for their development. These are the economic activities distributed in the fourth quadrant of the coordinate system (the so called 'Emerging Industries'). For Bulgaria these activities are: Information and communication (J), Financial and insurance activities (K), Real estate activities (L) and Arts, entertainment and recreation; other service activities; activities of household and extra-territorial organizations and bodies (R, S, T and U).

\section{ACKNOWLEDGEMENTS}

This document was supported by the grant No BG05M2OP001-2.009-0034-C01 „Support for the Development of Scientific Capacity in the University of Forestry", financed by the Science and Education for Smart Growth Operational Program (2014-2020) and co-financed by the European Union through the European structural and investment funds.

\section{REFERENCES}

[1] www.nsi.bg

[2] Dinc, M. (2002). Regional and Local Economic Analysis Tools. The World Bank, Washington $\mathrm{DC}, 44 \mathrm{p}$.

[3] Rupasingha, A., M. Patrick. Tools for Understanding Economic Change in Communities: Economic Base Analysis and Shift-Share Analysis, New Mexico State University Library, http://aces.nmsu.edu/pubs/_circulars/cr643A.pdf 
[4] Blakely, E., N. Leigh. (2013). Planning Local Economic Development. Theory and Practice, Fifth Edition, SAGE Publication, 461.

[5] Dogru, T., E. Sirakaya-Turk. (2017). Engines of Tourism's Growth: An Examination of Efficacy of Shift-Share Regression Analysis in South Carolina, Elsevier, Tourism Management, 58, 205-214.

[6] Elburz, Z., F. Gezici. (2012). Regional Development Policies and Industrial Employment Change in Turkey: A Shift Share Analysis (1992-2008), 52nd Congress of the European Regional Science Association: "Regions in Motion - Breaking the Path", 21-25 August, Bratislava, http://hdl.handle.net/10419/120750

[7] Goschin, Z. (2014). Regional Growth in Romania after its Accession to EU: A Shift-Share Analysis Approach, Elsevier, Procedia Economics and Finance, 15, 169-175.

[8] Herath, J., T. Gebremedhin, B. Maumbe. (2011). A Dynamic Shift-Share Analysis of Economic Growth in West Virginia, Journal of Rural and Community Development, 155-169.

[9] Islam, F., F. Sidding, F. Mubassirah. (2016). Economic Growth Analysis of Six Divisions of Bangladesh Using Location Quotient and Shift-Share Method, Bangladesh Res. Pub. J. 12 (2), 144-154.

[10] Evans, G. (2008). Spatial Shift-Share Analysis of the Leisure and Hospitality Sector on the Gulf Coast Following Hurricane Katrina, Southern Agricultural Economic Association, Dallas, 2008, 1-15.

[11] M. Khusaini. (2015). A Shift-Share Analysis on Regional Competitiveness - a Case of Banyuwangi District, East Java, Indonesia, Elesevier, Procedia - Social and Behavioral Sciences, 738-744.

[12] Mason, S., P. Zhu, J. Dyke. (2017). Regional Industry Analysis: An Approach for Economies Large and Smaller, Economic Development Quarterly, 31 (2), 128-138.

[13] Morrissey, K. (2016). A Location Quotient Approach to Producing Regional Production Multipliers for the Irish Economy, Papers in Regional Science, 95 (3), 491-506.

[14] Stoenchev, N. (2016). Kachestvoto na zhivot i spetsializatsiya na teritoriyata po ikonomicheski deynosti v Balgariya (statisticheski aspekti). Izdatelstvo „Intel Entrans“, S., 122 s.

[15] Stoencheva, TS. (2010). Regionalna ikonomika. Universitetsko izdatelstvo „Stopanstvo“, S., $160 \mathrm{~s}$.

[16] Svetikas, K. (2014). Strategic Planning For Regional Development: An Introductory Textbook, Mykolas Romeris University, Vilnius, 131.

[17] Papazov, E. (2006). Tehniki za obektivizirane na SWOT-analiza na regionalnoto razvitie. Ikonomicheski zhivot, br. 2.

[18] Stoychev, K. (2007). Opredelyane na znachenieto na toplivno energiyniya kompleks Maritsa-iztok v regionalnata ikonomika na oblast Stara Zagora chrez obektiviziran SWOT-analiz. Geografiya i regionalno razvitie. Nauchni konferentsii s mezhdunarodno uchastie. Sozopol, 2-12 s.

[19] Stoychev, K. (2008). Regionalen balans na promishlenoto proizvodstvo: struktura i optimizatsiya. Avtoreferat na disertatsiya, predstavena za prisazhdane na nauchna stepen „doktor“ po nauchna spetsialnost 01. 08. 02. „Ikonomicheska i sotsialna geografiya“. SU „Sv. K1. Ohridski”, Geologo-geografski fakultet, S., 60 s.

[20] https://ec.europa.eu/eurostat/data/database 